\title{
Patterns of Student Use of a College Library
}

\begin{abstract}
A tabulation was made of a sampling of book charges and their borrowers' class, sex, and grade point average. During a month-long period almost two out of three students borrowed no books. Freshmen borrowed more books per capita than did their elders. There was direct correlation between grade point average and the number of books charged. Slightly more books were charged per capita to women than to men. The implications of the high incidence of nonuse of libraries upon staffing are discussed.
\end{abstract}

$I$ N THE SPRING of 1962 a thirty-day study was made to determine the broad pattern of student use of the library at Eastern Illinois University. The data collected at that time were so disturbing-indicating that 63 per cent of the student body borrowed NO books during the period-that another similar survey was undertaken in the fall quarter of 1963. Both studies are reflected in this report, although to conserve space only the detailed breakdown from the earlier quarter on such matters as academic class, achievement, and sex is reported here.

The method used for both studies was as follows: all call slips for books from the closed stack were saved for a period of thirty days in the middle of each quarter. The call slips were arranged by student identification number. The university machine records department supplied the library with a complete list of students, arranged by student identification number. This list also included each

Mr. Barkey is Librarian at Texas College of Arts and Industries. student's class standing, sex, name, and cumulative grade point average. The staff then counted the number of call slips for each student and noted beside his name the number of books checked out. This study did not include reserve books.

Some background information might help in interpreting the statistical results that follow. The library building was completed in 1950. It is new and pleasantly lighted, and, although it is built in the "old manner"-two large reading rooms, reserve and reference, arranged on each side of a closed stack and circulation desk-it seems friendly and comfortable. The library staff at the time of this study was composed as follows: circulation, two librarians; reference, two librarians; cataloging, two librarians; acquisitions, one librarian; serials, one librarian. The book collection, numbering approximately one hundred ten thousand volumes, is a well-balanced undergraduate collection.

Table 1 indicates the books borrowed by all students. 
TABLE 1

Total number students

Number students borrowing no books

Percentage of students borrowing no books

Total students borrowing one book

Total students borrowing 2 or 3 books

Total students borrowing 4 to 10 books

Total students borrowing 10 or more books

Number or per cent borrowing one or more books

\begin{tabular}{|r|r}
\hline 1962 & 1963 \\
\cline { 2 - 2 } 2,967 & 3,847 \\
1,849 & 2,318 \\
$63 \%$ & $62 \%$ \\
264 & 446 \\
372 & 532 \\
381 & 421 \\
101 & 130 \\
1,118 & 1,529 \\
or \\
$37 \%$ & or \\
& $38 \%$ \\
\hline
\end{tabular}

As can be seen from the above, 62 per cent- 63 per cent of the student body borrowed no books. Table 2 is a summary table adapted from Knapp ${ }^{1}$ and Brans$\mathrm{comb}^{2}$ as a comparison.

The first of three student characteristics (academic class, achievement, and sex) were covered in the 1962 sample.

Knapp's study discovered that "there was a total increase in use of the library between the freshmen and sophomore years and a total increase in the use of the library between the junior and senior years." Branscomb found that in "Uni-

\footnotetext{
1 Patricia Knapp, College Teaching and the College Library (ACRL Monograph No. 23, [Chicago: ALA, 1959]), p.23.

${ }^{2}$ Harvie Branscomb, Teaching with Books: A Study of College Libraries (Chicago: Association of American Colleges, 1940), p.35.

${ }^{3}$ Knapp, op. cit., p.27.
}

TABLE 2

SumMary of Studies Showing No USE OF LibraRY

\begin{tabular}{|c|c|c|}
\hline & & $\begin{array}{l}\text { Per Cent } \\
\text { Withdrawing } \\
\text { No Books }\end{array}$ \\
\hline 2,292 & $\begin{array}{l}\text { Students in one university } \\
\text { 2nd half spring semester. }\end{array}$ & 42.0 \\
\hline 2,438 & $\begin{array}{l}\text { Students in } 5 \text { colleges } \\
9 \text { months }\end{array}$ & \\
\hline 836 & $\begin{array}{l}\text { Men students in "College B" } \\
\text { one semester }\end{array}$ & , \\
\hline 486 & $\begin{array}{l}\text { Women students one } \\
\text { semester }\end{array}$ & 28.0 \\
\hline 738 & $\begin{array}{l}\text { Students Knox College } \\
\text { one quarter }\end{array}$ & 48.51 \\
\hline 2,967 & $\begin{array}{l}\text { Eastern Illinois University } \\
30 \text { days }(1962)\end{array}$ & 63.0 \\
\hline 3,847 & $\begin{array}{l}\text { Eastern Illinois University } \\
30 \text { days (1963) }\end{array}$ & 62.0 \\
\hline
\end{tabular}

versity $A$ " the average number of withdrawals per student progressed evenly from 1.79 for freshmen to 4.97 for seniors. ${ }^{4}$ Our findings seem to be almost the reverse of these results. The freshmen seemed to be using the library more. An interesting fact is that 44 per cent of the freshmen borrowed one or more books compared to 35 or 36 per cent of the other academic classes.

Scholastic achievement in the 1962 study, because of certain mechanical problems in the machine records department, did not include graduate students and some freshmen. As Table 4 indicates, these findings include 2,449

4 Branscomb, op. cit., p.35.

TABLE 3

Comparison of Academic Class and Wrthdrawals

\begin{tabular}{|c|c|c|c|c|c|c|c|}
\hline & $\begin{array}{c}\text { Total } \\
\text { in } \\
\text { Class }\end{array}$ & $\begin{array}{c}\text { Per Cent } \\
\text { of } \\
\text { Total } \\
\text { Students }\end{array}$ & $\begin{array}{c}\text { Number and } \\
\text { Per Cent } \\
\text { of Class } \\
\text { Borrowing } \\
1 \text { or More } \\
\text { Books }\end{array}$ & $\begin{array}{c}\text { Per Cent } \\
\text { of } \\
\text { Total } \\
\text { Students } \\
\text { Borrowing }\end{array}$ & $\begin{array}{c}\text { Total } \\
\text { Number } \\
\text { Books } \\
\text { Borrowed }\end{array}$ & $\begin{array}{c}\text { Per Cent } \\
\text { of } \\
\text { Total } \\
\text { All } \\
\text { Books } \\
\end{array}$ & $\begin{array}{c}\text { Per Capita } \\
\text { Class Average } \\
\text { Number Book } \\
\text { Per Student } \\
\text { in Class }\end{array}$ \\
\hline Freshmen & 1,031 & 35 & 451 or 44 & 15 & 1,895 & 40 & 1.8 \\
\hline Sophomores & 674 & 23 & 238 or 35 & 8 & 847 & 17 & 1.2 \\
\hline Juniors & 627 & 21 & 226 or 36 & 7 & 1,014 & 21 & 1.6 \\
\hline Seniors & 455 & 15 & 161 or 35 & 6 & 675 & 14 & 1.4 \\
\hline Graduates & 150 & 5 & 42 or 28 & 1 & 252 & 5 & 1.7 \\
\hline Special and & & & & & & & \\
\hline Others & 30 & 1 & & & 130 & 2 & $\ldots$. \\
\hline Total & 2,967 & 100 & 1,118 & $\ldots \ldots$ & 4,863 & 100 & $\ldots$ \\
\hline
\end{tabular}


TABLE 4

Grade Point Averages Compared to Withdrawals

A 4.0 to A 3.5

B 3.0 to B 2.5

C 2.0 to $\mathrm{C} 1.5$

D 1.0 to $\mathrm{D} 0.5$

F 0.4 to 0.0

\begin{tabular}{r|c|r|c}
$\begin{array}{c}\text { Total } \\
\text { Number } \\
\text { Students }\end{array}$ & $\begin{array}{c}\text { Per Cent } \\
\text { of Grand } \\
\text { Total }\end{array}$ & $\begin{array}{c}\text { Number } \\
\text { Borrowing } \\
\text { at Least } \\
\text { 1 Book }\end{array}$ & $\begin{array}{c}\text { Per Cent } \\
\text { of Total } \\
\text { Group } \\
\text { Borrowing } \\
\text { at Least } \\
\text { 1 Book }\end{array}$ \\
\cline { 1 - 2 } & 4 & 75 & 62 \\
118 & 4 & 399 & 44 \\
907 & 37 & 529 & 39 \\
1,344 & 55 & 16 & 22 \\
73 & 3 & 1 & 14 \\
7 & & 1,020 & $\ldots$ \\
2,449 & $\ldots$ & &
\end{tabular}

of the 2,967 students enrolled in the spring 1962 quarter.

This seems to indicate that more of the better students use the library and that the lower the grade point average the fewer library withdrawals. Conclusions drawn from the comparison of grade point averages and library withdrawals are not very reliable, however. Table 5 is an example.

\section{TABLE 5}

Over-all Grade Point Averages Compared To Those of STUdents Borrowing Books

Over-all grade point average (all students)

Grade point average of students borrowing one or more books

Grade point average of students borrowing no books

In other words, a "C" or better could be earned without using the library; 56 per cent of those earning a "B" or "B-" did not use the library. Another way of putting this is that a total of 1,025 students earned from "A" to "B-"; however, of this total only 474 , or 46 per cent, withdrew books from the general collection. Branscomb, in describing a similar situation, said: "From the student's standpoint one could say that these students neglected the library's resources because they found they did not need to use them in order to do acceptable work."

Sex was significant only in the number of men or women using the general collection. More women withdrew books, but the average number of books withdrawn per male student shows very litthe difference from the average number withdrawn per female student.

Do these findings represent a rather dismal trend in library use? Or, is this merely the statistical picture of a disappointing "normal"? We, of course, have no way of knowing. Asheim has said: "Reporting the findings of research on reading is always a thankless task. ${ }^{6}$ In a related study on faculty use of Eastern Illinois University library, re-

\footnotetext{
s Branscomb, op. cit., p.47.

'Lester Asheim, "A Survey of Recent Research," in Conference of the Undergraduate and Lifetime Reading Interest (Ann Arbor: University of Michigan Press, 1959), p.3.
}

TABLE 6

WithdraWal By SEX

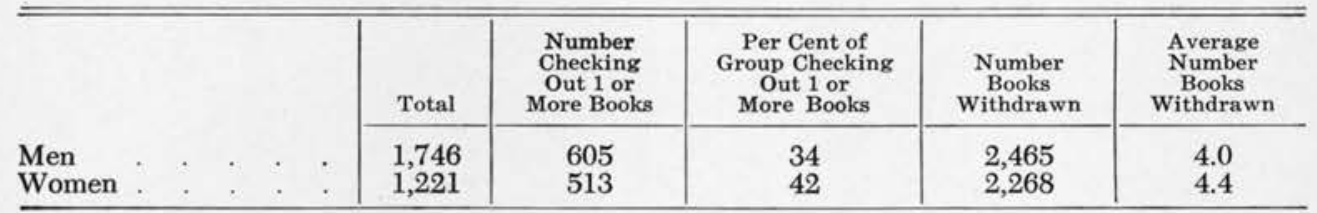


ported earlier, ${ }^{7}$ it was found that while the student population and gross book circulation doubled almost uniformly over a ten-year span, faculty use of the library, as reflected in such things as average number of books circulated per faculty member, declined an alarming 50 per cent in a ten-year period.

For fear that the statistical picture just presented be misunderstood, the following observations should be made. This study was made in years that saw the total library circulation increase nearly 30 per cent, to over one hundred ten thousand, a figure above average for a university of Eastern's size, and the all-time high for this institution. The general "climate of feeling" that surrounds library operations on the campus is favorable. The administration is library-minded, having obtained full faculty rank and status, plus regular academic vacations, for all of the professional library staff. The campus does not have that indefinable core of ill feeling toward the library that seems to be present on some campuses. We find that in the library's busiest years, without ignoring Parkinson's First Law, only 37 per cent and 38 per cent of the student

"Patrick Barkey, "More on the Absent Professors," Library Journal, LXXXVII (April 1, 1962), 1346. body withdrew at least one book in two sample months from the general collection. And this occurred during a time when the library was rushed enough to ask for an increase in student help halfway through the term and after much discussion of an increase in library hours. Is this the picture in other institutions now riding the enrollment tidal wave? Are all university libraries, busy though they are, merely operating at one-third or one-half capacity? Can the postwar increases in library use be explained simply as increases in student enrollment? And lastly, what is "capacity"? Are we to find, like the operations group that built the Polaris, that one overworked man can outperform two men operating at "capacity." The library in this study could not have absorbed another 30 per cent increase in use and still have offered anything approaching professional-level library service.

This study was undertaken to determine the statistical pattern, if any, of student use of a specific university library. It is not an attempt to present solutions to the complex of factors involved in the use-or nonuse-of that library. Perhaps the results presented here and the questions that arise from those results may be of value in the formation of future policies.

\section{Planning a Meal-Meeting?}

A NOvel table tent, which ships flat and folds into an ALA pyramid, might be used by hospitality chairmen planning library staff dinner meetings, local library club banquets, or district or state library association banquets. Request the table tent, which is mailed free, from Membership Promotion, ALA Headquarters, 50 East Huron Street, Chicago, 60611. 